the type varied considerably. A number of emergency departments were prepared to send staff outside to manage patients $(43 \%)$ or into the hot zone (11\%). This did not correlate with the level of PPE or decontamination facility available.

Conclusion: Disaster preparedness has improved in Australian EDs over the past two years in some areas, most notably equipment availability for PPE and decontamination. However, there are concerns about the perceived or actual levels of preparedness of some emergency departments and the need for funded education and training.

Keywords: Australia; chemical, biological, and radiological (CBR); decontamination; disasters; education; emergency departments; personal protective equipment; preparedness; training

Prehosp Disast Med 2005;20(3):s137-s138

\section{Role of Hospitals in Disasters}

M.W. Chaffee; ${ }^{1}$ N.S. Oster ${ }^{2}$

1. United States Navy, USA

2. The Methodist Hospital, Brooklyn, New York USA

Hospitals are depended upon to be a cornerstone of response to disaster, but many hospitals are not adequately prepared to respond effectively. This presentation will address the impact of disaster on hospitals, the evolving role of the health system in national security, and public expectations.

A discussion of current practices in hospital preparedness will examine why hospitals are vulnerable to disaster. Forces impacting hospital preparedness will be identified. The critical elements of a solid hospital preparedness program will be described along with chronic pitfalls in hospital preparedness.

The current state of the science in hospital preparedness for acute-onset disasters will be examined and gaps in current knowledge will be addressed.

The level of preparedness in dozens of hospitals in the United States and in other nations has been analyzed. A hospital preparedness program that was an award finalist in the 2004 Harvard University/Mitretek Innovations in American Government Homeland Security award was led by the authors.

Keywords: assessment; current practices; disasters; hospitals; preparedness

Prehosp Disast Med 2005;20(3):s138

\section{Resistance Factors to Rapid Response in Natural Disaster Scenarios \\ C.R. Jagger \\ Binscombe Medical Centre, United Kingdom}

Introduction: The frequency of natural disasters is increasing. Rapid response on a local, national, and sometimes, international scale is required to offset increasing levels of mortality and material loss. Many factors can frustrate or impede the rapid response of individuals and relief organizations. Each organization will encounter difficulties regarding rapid movement of personnel and appropriate equipment to a natural disaster zone. These may be specific to a particular organization, but common obstacles to rapid response exist as well. The hypothesis is that there will be common obstacles to rapid response encountered by the various relief organizations. This study seeks to gauge the opinions of those engaged in response strategies to natural disasters, regarding these resistance factors. This study is qualitative in approach and attempts to establish a priority "hit list" which could serve as material for intervention and improvement for the disaster relief organizations.

Methods: A research tool (questionnaire) was constructed based on findings from extensive meetings and discussions with those engaged in disaster relief, together with observations from first-hand experiences in the emergency relief effort in El Salvador after the earthquakes of 2001. The questionnaire was circulated to members of the World Association for Disaster and Emergency Medicine (WADEM), other emergency relief agencies, and nongovernment organizations, after an appropriate pilot study using a random sample of WADEM members.

The circulation of the questionnaires and collation of material from the responses is ongoing, but the bulk of the responses were received during 2002-2003.

Results: Responses were received from four main sources-WADEM, Tear Fund (NGO), some United Nations departments, and Search and Rescue teams. The WADEM members from 17 countries completed the questionnaires. Fourteen of the 46 "resistance factors" to rapid response listed on the questionnaire were highlighted by each respondent consistently.

Conclusions: The attention to resistance factors to rapid response using the sampling tool yielded a positive response. A pattern of consensus has emerged which is worthy of further study. The magnitude of a given event versus the state of readiness and capacity of the local hospital services and defense organizations is a key issue. Disaster mitigation and preparedness is now high on the agenda regarding disaster response. It behoves all engaged in disaster response to examine the efficiency of their particular organization and the systems employed, and to ask the question: "Could improvements be made in the response time to a given event and could resistance factors to rapid response be overcome?"

Keywords: natural disasters; relief; response

Prebosp Disast Med 2005;20(3):s138

Emergency Air Medical Services in Taiwan: Long Distance Aeromedical Evacuation of Patients From a Remote Island by a Chartered, Fixed-Wing Air Ambulance
S.H. Tsai, ${ }^{1}$ H.R. Wu, ${ }^{2}$ L.J. Cbi, ${ }^{3}$ L.H. Lu; ${ }^{4}$ T.S. Chen; ${ }^{5}$
M.R. Lin; ${ }^{1}$ W.T. Chiu ${ }^{6}$
1. Taipei Medical University, Taiwan
2. Chung Shan Hospital, Taiwan
3. International SOS, Taiwan
4. Department of Emergency Medicine, Mackay Memorial, Taiwan
5. Bureau of Public Health and Environmental Protection, Taiwan
6. Institute of Injury Prevention and Control, Taiwan

Background: There is an increasing demand for emergency air medical services (EAMS) in Taiwan. Geographic limitations, as well as physician shortages, on some outer islands of Taiwan have resulted in increased EAMS development on remote islands. 
Objectives: To determine the characteristics and outcome of patients transported by a long distance, chartered, fixedwing air ambulance.

Methods: Documented reports of 215 patients who received fixed-wing air ambulance EAMS from a remote island to Taiwan during a study period of two years were reviewed.

Results: In this study, all transports were completed within six hours and the flight distance was $>400 \mathrm{~km}(249$ miles). Approximately 25\% ( $n=54$ ) of patients were elderly (61-75 years). Most patients suffered from major illnesses $(66.0 \%, n=142)$. Trauma patients comprised about one third of the population $(34.0 \%, \mathrm{n}=73)$. The overall 24 hour mortality rate was $6.6 \%$. Of the in-flight interventions carried out by EAMS, nasogastric (NG) tube placement, inotropics, defibrillators, and resuscitation were used frequently among patient with poor outcomes. Low Glasgow Coma Scale scores, ventilator use, and resuscitation were highly associated with patient mortality. Age was not predictive of mortality (Tables 1,2, and 3).

Conclusions: The high transport rate and low mortality identified in this study indicate the benefits of long distance, patient repatriation from a remote island to better-equipped medical centers in Taiwan. The use of a physician-based alarm center and escort team supplied with advanced medical equipment carried on board should be encouraged in an attempt to provide a safe, long-distance, air ambulance evacuation.

\begin{tabular}{|c|c|c|c|c|c|}
\hline $\begin{array}{c}\text { Independent } \\
\text { variables }\end{array}$ & $\begin{array}{c}\text { Dependent } \\
\text { variable: } \\
\text { survival }\end{array}$ & Mean & $\begin{array}{c}\text { Standard } \\
\text { deviation }\end{array}$ & $f$-value & $p$-value \\
\hline \multirow{2}{*}{ Age (years) } & Expired & 53.9 & 25.2 & 0.727 & 0.395 \\
\cline { 2 - 6 } & Surviving & 48.4 & 23.2 & \multicolumn{2}{|c|}{} \\
\hline $\begin{array}{c}\text { Glasgow } \\
\text { Coma } \\
\text { Scores }\end{array}$ & Expired & 2.8 & 0.4 & 96.798 & $0.000^{*}$ \\
\cline { 2 - 6 } & Surviving & 12.8 & 3.8 & \multicolumn{3}{|c|}{} \\
\hline
\end{tabular}

Table 1-Discriminant analysis (Independent variables: age, gender, ventilator use, Nasogastric tube placement, Chest tube placement, inotropics use, and resuscitation; dependent variable: mortality; ${ }^{*}$ Fisher's exact test)

\begin{tabular}{|l|c|c|}
\hline & $p$-value & $\begin{array}{c}\text { Odds ratio } \\
\text { (95\% Confidence Interval) }\end{array}$ \\
\hline Ventilator use & 0.021 & $\begin{array}{c}0.64 \\
(0.006-0.666)\end{array}$ \\
\hline Resuscitation & 0.007 & $\begin{array}{c}0.024 \\
(0.002-0.356)\end{array}$ \\
\hline
\end{tabular}

Table 2-Predictive factors for mortality

\begin{tabular}{|c|c|c|c|c|}
\hline & $\begin{array}{c}\text { Expired } \\
\text { n (\%) }\end{array}$ & \begin{tabular}{|c|} 
Surviving \\
n (\%)
\end{tabular} & $\begin{array}{l}\text { Total } \\
\mathbf{n}(\%)\end{array}$ & p-value \\
\hline \multicolumn{4}{|l|}{ Ventilator use } & 0.000 \\
\hline With & $\begin{array}{c}13 \\
(92.9)\end{array}$ & $\begin{array}{c}44 \\
(22.0)\end{array}$ & $\begin{array}{c}57 \\
(26.6)\end{array}$ & \\
\hline Without & $\begin{array}{c}1 \\
(7.1)\end{array}$ & $\begin{array}{c}156 \\
(78.0)\end{array}$ & $\begin{array}{c}157 \\
(73.4)\end{array}$ & \\
\hline \multicolumn{4}{|c|}{ Glasgow Coma Scale scores } & 0.000 \\
\hline$<9$ & $\begin{array}{c}13 \\
(92.9) \\
\end{array}$ & $\begin{array}{c}29 \\
(14.4)\end{array}$ & $\begin{array}{c}42 \\
(19.5) \\
\end{array}$ & \\
\hline $9-12$ & $\begin{array}{c}0 \\
(0) \\
\end{array}$ & $\begin{array}{c}23 \\
(11.4) \\
\end{array}$ & $\begin{array}{c}23 \\
(10.7) \\
\end{array}$ & \\
\hline $13-14$ & $\begin{array}{c}1 \\
(7.1)\end{array}$ & $\begin{array}{c}16 \\
(8.0)\end{array}$ & $\begin{array}{c}17 \\
(7.9)\end{array}$ & \\
\hline$>15$ & $\begin{array}{c}0 \\
(0)\end{array}$ & $\begin{array}{c}133 \\
(66.2)\end{array}$ & $\begin{array}{c}133 \\
(61.9)\end{array}$ & \\
\hline \multicolumn{5}{|l|}{ Disease type } \\
\hline Trauma & $\begin{array}{c}9 \\
(64.3)\end{array}$ & $\begin{array}{c}64 \\
(31.8)\end{array}$ & $\begin{array}{c}73 \\
(34.0)\end{array}$ & 0.019 \\
\hline Illness & $\begin{array}{c}5 \\
(35.7)\end{array}$ & $\begin{array}{c}137 \\
(68.2)\end{array}$ & $\begin{array}{l}142 \\
(66) \\
\end{array}$ & \\
\hline \multicolumn{4}{|c|}{ Post-transfer admission } & 0.000 \\
\hline Abandoned & $\begin{array}{c}7 \\
(50.0) \\
\end{array}$ & $\begin{array}{c}0 \\
(0) \\
\end{array}$ & $\begin{array}{c}7 \\
(3.4)\end{array}$ & \\
\hline $\begin{array}{l}\text { Intensive care } \\
\text { unit }\end{array}$ & $\begin{array}{c}4 \\
(28.6)\end{array}$ & $\begin{array}{c}100 \\
(51.8)\end{array}$ & $\begin{array}{c}104 \\
(50.2)\end{array}$ & \\
\hline Ward & $\begin{array}{c}0 \\
(0)\end{array}$ & $\begin{array}{c}79 \\
(40.9)\end{array}$ & $\begin{array}{c}79 \\
(38.2)\end{array}$ & \\
\hline $\begin{array}{l}\text { Emergency } \\
\text { room }\end{array}$ & $\begin{array}{c}3 \\
(21.4) \\
\end{array}$ & $\begin{array}{c}14 \\
(7.3) \\
\end{array}$ & $\begin{array}{c}17 \\
(8.2) \\
\end{array}$ & \\
\hline \multicolumn{5}{|c|}{ In-flight interventions } \\
\hline Nasogastric tube & $\begin{array}{c}5 \\
(45.5)\end{array}$ & $\begin{array}{c}31 \\
(15.4)\end{array}$ & $\begin{array}{c}36 \\
(17.0)\end{array}$ & 0.023 \\
\hline Inotropics & $\begin{array}{c}9 \\
(81.8) \\
\end{array}$ & $\begin{array}{c}56 \\
(27.9)\end{array}$ & $\begin{array}{c}65 \\
(30.7)\end{array}$ & $0.000^{*}$ \\
\hline $\begin{array}{l}\text { Automated } \\
\text { external } \\
\text { defibrillator }\end{array}$ & $\begin{array}{c}5 \\
(45.5)\end{array}$ & $\begin{array}{c}1 \\
(0.5)\end{array}$ & $\begin{array}{c}6 \\
(2.8)\end{array}$ & $0.000^{*}$ \\
\hline Resuscitation & $\begin{array}{c}5 \\
(45.5)\end{array}$ & $\begin{array}{c}1 \\
(0.5)\end{array}$ & $\begin{array}{c}6 \\
(2.8)\end{array}$ & $0.000^{*}$ \\
\hline
\end{tabular}

Table 3-Distribution frequencies between expired and surviving transported patients ("Fisher's exact test)

Keywords: air ambulance; emergency air medical services (EAMS); fixed-wing; long distance; repatriation; Taiwan

Prebosp Disast Med 2005;20(3):s138-s139 